\title{
INFLUENCE OF CONTRACEPTIVE GESTOGEN PILLS ON SEXUAL BEHAVIOUR AND THE SPREAD OF GONORRHOEA *
}

\author{
BY \\ LENNART JUHLIN AND STURE LIDÉN \\ Department of Dermatology, University Hospital, Uppsala, Sweden
}

The introduction and widespread use of antibiotics in the last few decades have altered public attitudes towards venereal diseases and the previous fear of their consequences has been replaced by indifference, which has in turn contributed to sexual permissiveness. It has been contended that the removal of fear of pregnancy by the increasing availability and use of contraceptive gestogen pills and intrauterine devices has also contributed to increased sexual activity and has thus possibly become a new factor facilitating the spread of venereal infections (Idsøe and Guthe, 1967).

The use of contraceptive gestogen pills has increased in Sweden during the last two years and the present study was undertaken to obtain answers to the following questions:

(1) Does the use of gestogen contraceptive pills lead to an increase of promiscuous behaviour?

(2) What is the effect of such pills on the frequency of sexual intercourse?

(3) Is there evidence that such hormonal ingestion alters the susceptibility of the mucosa to gonococcal infection?

(4) Has the use of condoms-so far considered the best protection against venereal diseases - decreased since the introduction of the gestogen pills?

\section{Material and Methods}

\section{Patients}

The Venereal Disease Clinic of the University Hospital, Uppsala, serves an area of approximately 100,000 people, of whom 19,000 (19 per cent.) were registered as university students at the time of the present study. The investigation involved a total of 522 patients who attended this venereal disease outpatients clinic from September, 1967, to February, 1968. Among these 522 patients, 250 (47.8 per cent.) were

\footnotetext{
$\star$ Received for publication March 3, 1969.
}

females and 272 (52.2 per cent.) males. Of the total patients of both sexes, 182 (34.8 per cent.) were university students. Among the 250 females there were 71 (28.4 per cent.) university students and among the 272 males there were 111 ( 40.7 per cent.). These categories and the age and sex distribution of the study group are contained in Table I.

TABLE I

CATEGORY, AGE, AND SEX DISTRIBUTION OF PATIENTS

\begin{tabular}{|c|c|c|c|c|c|}
\hline Sex & Category & $\begin{array}{l}<20 \\
\text { yrs }\end{array}$ & $\begin{array}{c}20-25 \\
\text { yrs }\end{array}$ & $\begin{array}{l}>25 \\
\text { yrs }\end{array}$ & Total \\
\hline Male & $\begin{array}{l}\text { University } \\
\text { students } \\
\text { Non-students }\end{array}$ & $\begin{array}{r}4 \\
27\end{array}$ & $\begin{array}{l}86 \\
79\end{array}$ & $\begin{array}{l}21 \\
55\end{array}$ & $\begin{array}{l}111 \\
161\end{array}$ \\
\hline Female & $\begin{array}{l}\text { University } \\
\text { students } \\
\text { Non-students }\end{array}$ & $\begin{array}{r}6 \\
73\end{array}$ & $\begin{array}{l}57 \\
80\end{array}$ & $\begin{array}{r}8 \\
26\end{array}$ & $\begin{array}{r}71 \\
179\end{array}$ \\
\hline \multicolumn{2}{|c|}{ Total } & 110 & 302 & 110 & 522 \\
\hline
\end{tabular}

A clinical diagnosis of gonorrhoea was confirmed by positive cultures in 147 (54 per cent.) of the males and 168 (67 per cent.) of the females. The patients in whom gonorrhoea was not diagnosed by these criteria had been named as contacts of patients with proven gonorrhoea. In accordance with the venereal disease legislation in force in Sweden at the time of the study, these sexual partners are obliged to undergo medical examination.

\section{Method of Survey}

All patients were informed that factors which might contribute to the spread of gonorrhoea were being investigated. They were asked if they would participate in such an investigation and give honest replies to intimate questions, and all except three replied to the questions posed orally by the special interviewer. The replies were recorded in a questionnaire. To prevent misunderstanding, all questions were carefully explained. The patients were asked to write down the number of their sexual partners during the last year and the number 
of days per month they estimated that they had sexual intercourse. It was explained that it was important to know how much time had elapsed before they suspected they had been exposed to gonorrhoea. An affirmative in reply to the question whether male partners always or nearly always used condoms was recorded as "yes"; "no" meant that they rarely or never used condoms. When completed the questionnaire was deposited by the patient through a slot into a sealed box.

\section{Results}

These are presented in Tables II to VI.

(1) Of the different contraceptives, oral gestogen pills were predominant among females examined. They were used by $\mathbf{7 0 . 4}$ per cent. of the students and 50.1 per cent. of the non-student patients (Table II). Among the latter, gestogen pills were used by 36 per cent. of those under 20 years of age and by 63 per cent. of those between 20 and 25 years. Diaphragms were used by eight patients and intrauterine loops by two patients in both groups together.

TABLE II

STUDENTS AND NON-STUDENTS USING CONTRACEPTIVES

\begin{tabular}{l|r|r|r|r}
\hline \multicolumn{1}{c|}{$\begin{array}{c}\text { Type of } \\
\text { Contraceptive }\end{array}$} & \multicolumn{2}{|c|}{ Students } & \multicolumn{2}{c|}{ Non-students } \\
\cline { 2 - 3 } & No. & Per cent. & No. & Per cent. \\
\hline Pills & 50 & $70 \cdot 4$ & 91 & $50 \cdot 1$ \\
Diaphragm & 6 & $8 \cdot 4$ & 2 & $1 \cdot 1$ \\
Intrauterine loop & 0 & 0 & 2 & $1 \cdot 1$ \\
Condom & 40 & $36 \cdot 0$ & 40 & $24 \cdot 3$ \\
\hline
\end{tabular}

(2) Patients less than 20 years of age had more partners than those over 25 years (Table III).

TABLE III

FREQUENCY OF INTERCOURSE PER MONTH AND NUMBER OF PARTNERS PER YEAR OF PATIENTS USING AND NOT USING CONTRACEPTIVE PILLS. MEAN $\pm S E$

\begin{tabular}{|c|c|c|c|c|}
\hline Pills & Age (yrs) & $\begin{array}{l}\text { No. of } \\
\text { Women }\end{array}$ & $\begin{array}{c}\text { Frequency } \\
\text { of } \\
\text { Intercourse }\end{array}$ & $\begin{array}{c}\text { No. of } \\
\text { Partners }\end{array}$ \\
\hline Taken & $\begin{array}{r}<20 \\
20-25 \\
>25\end{array}$ & $\begin{array}{l}31 \\
91 \\
19\end{array}$ & $\begin{array}{l}7 \cdot 2 \pm 1 \cdot 0 \\
7 \cdot 5 \pm 0 \cdot 5 \star \star \\
6 \cdot 1 \pm 1 \cdot 6\end{array}$ & $\begin{array}{l}3.7 \pm 0.5 \\
3.4 \pm 0.3 \\
2.4 \pm 0.4\end{array}$ \\
\hline Not taken & $\begin{array}{r}<20 \\
20-25 \\
>25\end{array}$ & $\begin{array}{l}48 \\
46 \\
15\end{array}$ & $\begin{array}{l}5 \cdot 7 \pm 0.9 \\
5 \cdot 1 \pm 0.9 \\
5.9 \pm 2.0\end{array}$ & $\begin{array}{l}3 \cdot 3 \pm 0.3 \\
2 \cdot 5 \pm 0 \cdot 2 \\
2 \cdot 0 \div 0.3\end{array}$ \\
\hline
\end{tabular}

$x<00.05$.

$\star \star \mathbf{P}<0.01$.

P-The probability that the difference between patients with and without pills is caused by random factors

Patients between 20 and 25 years taking gestogen pills had 36 per cent. more sexual partners than those of the same age not taking pills $(P<0.05)$;
20 per cent. of all women taking pills had more than ten partners per year and 26 per cent. one partner. The same percentages were found among those not taking pills. Among the patients having two to ten partners, the mean number of such partners was probably higher in those using pills than in those not using them $(P<0.05)$.

The frequency of sexual intercourse per month was about 47 per cent. higher among patients aged 20-25 years taking pills $(P<0.01$; Table III). The patients' replies to the question whether the number of partners or the frequency of sexual intercourse had increased after they started using pills are shown in Table IV. Although most patients believed that their sexual activities had not changed significantly, there was an increase rather than decrease in the number of partners and in the frequency of intercourse after they had started using gestogen pills $(P<0.01)$. About one-fifth of the patients were unable to reply to these questions, mainly because of irregular sexual activity.

TABLE IV

NUMBER OF PATIENTS DECLARING A CHANGE IN FREQUENCY OF SEXUAL INTERCOURSE AND NUMBER OF PARTNERS AFTER COMMENCING TO USE CONTRACEPTIVE GESTOGEN PILLS

\begin{tabular}{c|c|c}
\hline $\begin{array}{c}\text { Frequency of } \\
\text { Intercourse }\end{array}$ & $\begin{array}{c}\text { No. of Patients } \\
\text { Stating Frequency } \\
\text { of Intercourse }\end{array}$ & $\begin{array}{c}\text { Patients stating } \\
\text { No. of Partners }\end{array}$ \\
${$\cline { 1 - 2 }$} }$ & 43 & 25 \\
Decreased & 9 & 10 \\
Unchanged & 63 & 84 \\
\hline
\end{tabular}

(3) A diagnosis of gonorrhoea was made as frequently among those using pills as among those not using them (Table V). A history of previous gonococcal infection was noted in 12 per cent. of the female university students and 30 per cent. of the non-students. There was no difference in the percentage of previous infection in the women taking pills compared to those not taking pills.

TABLE V

PATIENTS WITH :POSITIVE GONOCOCCAL CULTURES AMONG THOSE USING AND NOT USING CONTRACEPTIVE GESTOGEN PILLS

\begin{tabular}{|c|c|c|c|c|c|c|}
\hline \multirow[b]{2}{*}{ Pills } & \multicolumn{2}{|c|}{$\begin{array}{l}\text { University } \\
\text { students }\end{array}$} & \multicolumn{2}{|c|}{ Non-students } & \multicolumn{2}{|c|}{ Total } \\
\hline & $\begin{array}{l}\text { Per } \\
\text { cent. }\end{array}$ & No. & $\begin{array}{l}\text { Per } \\
\text { cent. }\end{array}$ & No. & $\begin{array}{c}\text { Per } \\
\text { cent. }\end{array}$ & No. \\
\hline $\begin{array}{l}\text { Taken } \\
\text { Not taken }\end{array}$ & $\begin{array}{l}52 \\
52\end{array}$ & $\begin{array}{l}26 \\
11\end{array}$ & $\begin{array}{l}77 \\
69\end{array}$ & $\begin{array}{l}70 \\
61\end{array}$ & $\begin{array}{l}68 \\
66\end{array}$ & $\begin{array}{l}96 \\
72\end{array}$ \\
\hline
\end{tabular}

(4) Of male student patients 36 per cent. and of the male non-student patients 24.3 per cent. used condoms; 40 per cent. of those below 20 years 
of age used condoms. Patients having more than ten partners per year used condoms to the same extent as those with only one to three partners (Table VI). This Table also shows that the use of condoms was about twice as frequent among those having intercourse only once per month as among those having intercourse on more than ten occasions.

TABLE VI

PERCENTAGE OF PATIENTS USING CONDOMS ACCORDING TO NUMBER OF PARTNERS AND FREQUENCY OF INTERCOURSE

\begin{tabular}{|c|c|c|c|c|c|c|c|}
\hline \multicolumn{4}{|c|}{ Number of Partners per Year } & \multicolumn{4}{|c|}{$\begin{array}{c}\text { Monthly Frequency of } \\
\text { Intercourse }\end{array}$} \\
\hline 1 & $2-3$ & 4-10 & 10 & 1 & $2-4$ & $5-10$ & 10 \\
\hline 25 & 25 & 36 & 28 & 42 & 32 & 29 & 20 \\
\hline
\end{tabular}

Four non-student females using gestogen pills stated that their partners used condoms. Among those not taking pills the partner used condoms in 71 per cent. of the university students and 27 per cent. of the others.

\section{Discussion}

Though the majority of female patients declared that there had been no change in the number of partners after starting to use contraceptive pills, 25 stated that the number of partners had increased whereas only ten had a decreased number of partners after starting to take pills. When the mean number of partners of all patients between 20 and 25 years of age was estimated, an increase of 36 per cent. was found in the group using pills. The question whether the use of pills gives rise to increased promiscuity must therefore be answered in the affirmative. It is likely that this may contribute to an increased spread of gonorrhoea. An increased number of partners was more frequent among young people and a shift of gonorrhoea to younger ages will thus also increase its spread. This makes it difficult to evaluate the importance of the increased number of partners associated with the use of pills. We investigated pill usage in a similar group of women attending the clinic in 1966 (Juhlin, 1968), and since that time it has increased from 23 to 56 per cent. The age distribution is the same, but the number of patients with gonorrhoea treated in the clinic has increased by 10 per cent. This figure depends, however, on many factors and cannot be analysed further on the basis of the present data.

As regards the effect of oral contraceptives on the frequency of intercourse, we found that they increased the frequency by about 25 per cent. in the student and non-student group as a whole. The probable reason for this is the feeling of safety from conception when using contraceptive pills; it does not necessarily mean that the pills cause increase in libido. Reports in the literature on the effect of the pills on libido as such are divergent (Drill, 1966; Larsson-Cohn, 1966), both increase and decrease having been reported. Enjoyment of sexual intercourse is often found to be increased (Larsson-Cohn, 1966, Nilsson, Jacobson, and Ingemanson, 1967) or not affected (Nilsson and Sölvell, 1967).

Although oral gestogen pills may be held to increase the susceptibility of the mucosa to gonococcal infection, we found no evidence of this, since gonorrhoea was diagnosed to the same extent among those taking pills as among the controls. Since the women not using pills more often had partners using condoms than those using pills, this should have tended to decrease the frequency of gonorrhoea in this group. The absence of such a decrease may be due to the fact that the partners only used condoms on certain occasions as a contraceptive and even then not during the entire intercourse in an attempt to prevent venereal disease. If condoms had been used regularly and during the entire exposure time, the partners would have been unlikely to have acquired gonorrhoea. The possibility also exists that the pills decrease the susceptibility of the mucosa to gonorrhoea.

It should be pointed out that a similar incidence of gonorrhoea among those using and not using gestogen pills does not mean that their use has no effect on the spread of gonorrhoea. The increased sexual activity among patients taking pills probably increases their proportion in clinic patients.

On investigating the use of contraceptives by the patients attending the clinic in 1966, we found that 18 per cent. of the non-students and 48 per cent. of the University students used pills. In 1968, the total percentage of patients using pills was more than doubled. The increased use of pills was not, however, accompanied by a decreased use of condoms, which were still used by about one-third of the men. This is the same figure as was found previously. Only four of the patients taking pills had partners using condoms. In the earlier investigation 54 per cent. of the women said that one of the partners used a contraceptive. This figure is now increased to 73 per cent. due to increased use of contraceptive pills.

\section{Summary}

The influence of the use of contraceptive gestogen pills on human sexual behaviour and on the possible 
spread of gonorrhoea was investigated among $\mathbf{5 2 2}$ patients attending the Venereal Disease Clinic in Uppsala, Sweden, from September 1967, to February, 1968. Among the 250 women, 71 (28.4 per cent.) were university students, and fifty of these (70.4 per cent.) used contraceptive pills. Among 179 non-student female patients, 91 (50.1 per cent.) used contraceptive pills. In 1966-about a year before the present study-the corresponding findings were 48 and 18 per cent. respectively. This considerable increase in the use of contraceptive pills was not accompanied by a decrease in the use of condoms, which were used by 30 per cent. of the men, as in 1966.

The number of sexual partners per year and the frequency of intercourse were significantly higher in the women taking pills than in the others, and were highest in the age group 20 to 25 years. In the whole study group more persons stated that the number of partners and the frequency of sexual intercourse had increased after starting to use contraceptive pills. It is considered that this increase in sexual activity probably increases the risk of gonococcal infection. Gonorrhoea was diagnosed in 67 per cent. of the women. The remainder investigated were named as partners of patients with diagnosed disease. A diagnosis of gonorrhoea was made as frequently among those using pills as among those who did not. There is thus no evidence that the susceptibility of the mucosa to gonococcal infection is increased by the use of contraceptive gestogen pills.

The authors wish to thank Dr. Barbro Lewin and Miss Barbro Westrin for carefully interviewing the patients.

This study was supported by the Swedish Medical Research Council (Project No. B68-19X-769-03).

\section{REFERENCES}

I)RILL, V. A. (1966). "Oral Contraceptives", p. 110-111. McGraw-Hill, New York.

IDSøE, O., and Guthe, T. (1967). Brit. f. vener. Dis., $43,227$.

Juhlin, L. (1968). Acta derm.-venereol. (Stockh.), 48, 82 .
Larsson-Cohn, U. (1966). Acta obstet. gynec. scand., 45, 499.

Nilsson, Å., Jacobson, L., and Ingemanson, C. A. (1967). Ibid., 46, 537.

Nilsson, L., and Sölvell, L. (1967). Ibid., 46, Suppl. 8, "Studies on Oral Contraceptives".

Influence des pilules contraceptives à base de gestogènes sur le comportement sexuel et la diffusion de la gonococcie

\section{SOMMAIRE}

On étudia l'influence de l'utilisation des pilules contraceptives à base de gestogènes sur le comportement sexuel humain et sur la diffusion possible de la gonococcie chez 522 malades qui se présentèrent entre Septembre 1967 et Février 1968 à la Clinique Vénéréologique d' Upsala (Suède). Parmi les 250 femmes, 71 $(28,4$ pour cent) étaient des étudiantes de l'Université et 50 d'entre elles (70,4 pour cent) employaient les pillules contraceptives. Pour les 179 malades qui n'étaient pas étudiantes, 91 (50,1 pour cent) recouraient aux pilules. En 1966-à peu près un an avant l'étude présente-les chiffres étaient respectivement de 48 et de 18 pour cent. Cette augmentation important de l'emploi des pilules contraceptives ne fut pas accompagnée par une diminution de l'emploi du préservatif qui était employé par 30 pour cent des hommes, comme en 1966.

Le nombre des partenaires sexuels par année (et la fréquence des rapports) fut significativement plus élevé chez les femmes prenant des pilules.que chez les autres, le maximum correspondant au groupe d'âge de 20 à 25 ans. Dans la totalitè du groupe étudié, la plupart des personnes précisèrent que le nombre des partenaires et la fréquence des rapports avait augmentè après qu'elles eurent commencé à employer les pilules. On considère qu'à cette augmentation de l'activité sexuelle correspond probablement une augmentation du risque gonococcique. La gonococcie fut trouvée chez 67 pour cent des femmes. Les autres personnes sur lesquelles porta la recherche avaient été désignées comme partenaires de malades chez lesquels on avait diagnostiqué la maladie. Le diagnostic de gonococcie fut fait aussi souvent chez les femmes utilisant la pilule que chez celles qui ne l'employaient pas. Ainsi, il n'y a pas d'évidence que la sensibilité de la muqueuse à l'infection gonococcique soit augmentée par l'emploi des pilules contraceptives àjbase de gestogènes. 